\title{
Innovation Management Perceptions of Principals
}

\author{
Aslı Ağıroğlu Bakır \\ Correspondence: Aslı Ağıroğlu Bakır, Turgut Özal Anatolian High School, Çarmuzu, Malatya, Turkey
}

Received: March 6, 2016 Accepted: March 26, 2016 Online Published: March 30, 2016

doi:10.11114/jets.v4i7.1505

URL: http://dx.doi.org/10.11114/jets.v4i7.1505

\begin{abstract}
This study is aimed to determine the perceptions of principals about innovation management and to investigate whether there is a significant difference in this perception according to various parameters. In the study, descriptive research model is used and universe is consisted from principals who participated in "Acquiring Formation Course Management II", organized by Malatya Provincial Directorate of National Education. Sample is formed from 233 volunteer principals, who answered the data collection tool properly and completely. As the data collection tool, "Innovation Management Scale for Schools" developed by Bülbül (2012a) is used. In order to determine principal's perceptions about their competency level of innovation management, descriptive statistical calculations on the dataset are conducted. The lowest and the highest scores, standard deviation scores and arithmetic means are calculated. In addition, to determine principals' perceptions of their competence level of innovation management and its relationship with personal variables, t-test and one-way variance analysis (ANOVA) are performed through the data obtained. If ANOVA test results with significant differences, the multiple comparison tests are used to determine from which group or groups the difference is originated. In case of equal distribution of the group variances, Scheffe test is used for the multiple comparisons of average scores. According to results, principals' perceptions of innovation management as a whole correspond to "strongly agree" and for dimensions, "totally agree" level for "Organizational Culture and Structure" and "Project Management" dimensions and" strongly agree" for "Input Management" and "Innovation Strategy" dimensions.
\end{abstract}

Keywords: innovation, innovation management, principal

\section{Introduction}

Innovation carries a meaning which not only captivates but also frighten. According to this point of view, innovation is good because it gives a chance to improve and innovation is bad because it causes to move away from the customary values and requires addressing new and unknown. That is the two-way approach which determines how innovation is perceived in an organization and where the process goes. One person, an organization, a group or the whole community; their perceptions of the introduced innovation is decisive on the future of the individual or the society.

The term innovation is generally defined as the process of development, adaptation and putting these into practice (Comeaux, 2013). To replace the old, harmful or unsatisfactory with the new, useful and the satisfactory ones (TDK, 2015); development of already known products and processes, creation of new methods and eliminate the old ones (Matthews, 2003) are all embedded in the definition of innovation. According to Uzkurt (2008: 19-31), innovation has social and organizational aspects. Social aspect of innovation is increasing the life quality and welfare of the society. Organizational aspects are its being a process and continuous fact of the competition, attributing to the problem solving process and providing integration. Besides these, combination of these qualities creates social-organizational aspect of the innovation as expressed below:

Social-organizational aspects of the innovation:

- Making changes in people's lives

- Creating economic and social value

- Product of an environment that supports the innovation

- A vehicle for adaptation and integration

- Carrying an expansionistic characteristic.

The term innovation has a greater value in the field of management in the last three decades. Maybe that is because the organizations have realised that the secret to be a leader, to struggle and to survive is hidden behind innovation. This 
awareness uncovers new products, applications, programs, technologies, reforms and more complex structures (Comeaux, 2013).

During the innovation process, there is both creation and improvement (Matthews, 2003). Any innovation initiative is risky and full of difficulties. However, individuals and organizations that seek for innovation never give up looking for more effective and appropriate ways of investigating the practices of innovation (Markee, 1997). It wouldn't be wrong to accept that the term innovation is the key point for the success and the continuality of an organization. The organizations which have internalized an innovative point of view and put this into practice can keep on being in the global circle and won't be isolated from the improvements. The conditions of global competition express the reality that only the organizations concentrate on innovation and innovative culture can be different and efficient (Bülbül, 2012a). The changing nature of the market, changing demands, and needs of the information society envisage continuous innovation. It is not possible to respond these changing needs without innovation (Matthews, 2003). This determination shows that innovation not only ensures organizational efficiency but also it has an impact on the continuity of the organization (Goyal \& Pitt, 2007: 48).

Innovation shouldn't be comprehended as an abstract term as the implementation process is the main factor. All the elements of the organization, values, culture, working conditions and even the organizational goals can be affected by the innovation process (Sultana, 2001: 5). The connection between the organizational culture and innovation has a key position for the success of the change carrying the characteristic of innovation (Cornican \& Sullivan, 2004). The acceptance or the refusal reaction of the organization is decisive in the process of change and innovation that the organisation going to face. Any change should be out of the control of the organization, as the change can stand both for the development and the end. That is the reason why change has to be planned, functional and under control (Beycioglu \& Aslan, 2010: 154).

\subsection{Education and Innovation}

Schools are important instruments not only for students but also for social and national development (Wiseman, 2014: 252). It is obvious that information has to be shared among the social structures especially through individuals in order to realize an economic growth of the countries and increase the competition competencies (OECD, 2001). The main body of this information transfer and sharing is education. The inevitability of change, like all social institutions, it is also the case for educational institutions. Schools should be the cradle of innovation is a demand on a global scale (Perillo, 2007: 621). Fullan (2002b) underlines the reality that although schools are the basic elements of this process, they can be accepted as weak about the transformation and sharing of information. Explaining the situation with the hard and challenging school conditions as well as with the poor school culture, Fullan considers them as significant drawbacks to the innovation process. Nature and the reflections of most of the innovative approaches cannot be understood precisely. If people participate in the innovation process voluntarily or not, in each condition they can have ambivalence about its meaning, structure and results (Fullan, 2007). Most of the innovation affords in education conclude in frustration instead of success. One of the most important reasons of this result is ignoring the implementation process (Fullan, 1992).

Acceptance of the innovation as a significant approach and giving the necessary contribution to its implementation are two main domains. The schools which have the individuals, structures and cultures that reveal and support changes, are more ready to adapt and adopt the philosophy of innovation (Göl \& Bülbül, 2012). And it is not surprising that the ones who try to start an innovation movement want to implement it on the schools which have attracted the attention of society since from past to present (Argon \& Özçelik, 2008). For Beycioğlu \& Aslan (2010: 168), it is essential to examine schools for some features which would help them to realize this process in the best way and prepare them for the requirements of the age they are in. The features that are going to make the schools ready for the innovation process are like these:

Schools have to;

- be open to the society and emotional side of the students,

- accept social diversity,

- pay attention to high technology,

- improve and preserve their moral value in society,

- work in coordination with the other and higher positions,

- teach democracy and be democratic while teaching,

- be ready for today's competitive world,

- stand out against the harmful effects of the environment without severing the ties to the concrete side of life, 
- $\quad$ question their own structures while putting them all into practice.

\subsection{Principals and Innovation Management}

Human-beings feel anxiety, fear, danger, risk taking and panic besides excitement, energy, joy and development about innovation. And it is the time for leadership to manage these feelings when they increase. It is not always possible to perceive the results of innovations in advance; they can be very risky and destructive as well as improving and rewarding. This uncertainty can only be surpassed by the leader figure that has a vision of team work and ability to take risks. The success gained is closely related with the perceptions of all stakeholders (Boydak-Ozan \& Karabatak, 2013; Fullan, 2014).

It needs to approach the situation from a supportive point of view to actualize the innovations in educational fields. All the stakeholders besides principal have to share the responsibility about improving themselves of innovation management (A ̆̆ıroğlu Bakır \& Aslan, 2014; Aslan \& Ağıroğlu Bakır, 2015). Not only producing new ideas but also putting them into practice (Adair, 2008), showing an accepting attitude instead of resistance towards innovation beginning from the leader to all the elements of the organization are important facts to carry out innovation in an organization. Effective way of innovation management includes risk taking (Borgelt \& Falk, 2007).

School effectiveness literature requires the principal to be also equipped with strong leadership skills. These skills when supported with the attitudes of attaching importance to the innovation and risk taking in implementation process can bring out significant outcomes (Harris et. all, 2003). In today's world, many features attributed to principals are also compatible with the requirements of innovation process. Among these are trying to implement what he has learned by supporting idea of change, encouraging and assisting all the school members about learning and decision making, having a visionary point of view about technologic developments, being aware of the fact that school is not an independent structure but a sophisticated institution as a result of the interaction to society can be listed. It is principals' and teachers' responsibility to inform and convince all the other school members of innovation and its probable refection on organization's effectiveness. The maximum attribution about reaching the goals of the organization can only be possible with the dynamism of this innovation process (Beycioğlu \& Aslan, 2010; Van den Berg, Vandenberghe \& Sleegers, 1999).

The principals who exhibit a broad and inclusive whole concept of leadership are likely to make deeper and longer lasting impact on their organizations. Fullan (2002a) underlines the idea that the future's principals have to be equipped with conceptual thinking skills, ability to see the whole picture and believe in team work. In fact, the innovation approach in the world of business and education is getting closer day by day and this situation necessitates a new and varied action plan. There is a need for change and improvement in whole system. In this aspect, innovation and change not just for one but for all the school in the area might bring a well-functioning process with itself (Fullan, 2002a). Such a process can only become real by an appropriate leadership approach.

There has been a remarkable increase in studies of innovation in the last few decades. By the help of new technologies and implications, this number is rising up every day. As the whole world, there have also been some recently conducted researches (Ak, 2006; Beycioğlu \& Aslan, 2010; Boydak-Ozan \& Karabatak, 2013; Bülbül, 2012a, 2012b; Göl, 2012; Göl, \& Bülbül, 2012; Helvac1, 2004; Kabakçı, 2008; Karataş, Gök, \& Özçetin, 2015; Özdemir \& Cemaloğlu, 2000; Sönmez, 2005; Taş, 2007; Top, 2011) which examine the interaction of innovation, change, transformation and education according to various aspects in Turkey. When all these taken into account, it is seen that innovation management is a rising research topic and this study may attribute to the current literature and the process of functioning of schools in this aspect.

An organization's perception and acceptance form of innovation mostly depends on administrator's point of view and introducing the matter to the members. Any kind of administrator who sees the future of his organization on the decisions concerted according to changing circumstances is expected to behave accordingly. This expectation is also valid for principals. So it is obvious that how the principals perceive and evaluate themselves has dramatic result on the innovation period of schools. In this study, it is tried to put forth the principals' perceptions of innovation and innovation management and the results and implications are discussed.

This study is aimed to determine the perceptions of school principals about innovation management and to investigate whether there is a significant difference in this perception according to various parameters. The research questions are:

1. What are the perceptions of principals about the innovation management and its dimensions?

a) Input management

b) Innovation Strategy

c) Organizational culture and structure 
d) Project management

2. Is there a significant difference in principals' perceptions of innovation management and its dimensions according to some variables (Gender, Major, Education level, Faculty, Stage of schools they work, their professional year of experience, Number of students in the school variable, Number of teachers in the school variable)?

\section{Method}

\subsection{Research Model}

The present study is aimed to determine the perceptions of school principals about innovation management and to investigate whether there is a significant difference in this perception according to various parameters by using descriptive research model (Karasar, 2008).

\subsection{Population and Sample}

Universe of this study is consisted from school principals who participated to "Acquiring Formation Course Management II", organized by Malatya Provincial Directorate of National Education and held between 14- 18.09.2015. Instead of taking a sample from the universe, scale was applied to all of the principals attended to the course during the research period. Sample is formed from 233 volunteer school principals, who answered the data collection tool properly and completely.

\subsection{Data Collection Tool}

In this study, the data collection tool "Innovation Management Scale for Schools" developed by Bülbül (2012a) was used. The development process of the scale was conducted on 216 school principals. In order to determine the structural validity of the scale, exploratory and confirmatory factor analyses were applied. The scale was found to be consisted of four dimensions and have fivefold 32 Likert-type items as a result of exploratory factor analysis. The total amount of equity was found to be 20.2 and variance explained by equity is $62.99 \%$. Load factor values of the items on the scale ranged between 0.51 and 0.77 and four-factor structure of the scale was confirmed by also confirmatory factor analysis. Corrected total correlations of the scale items ranged from 0:39 to 0.77. T-test results, conducted between the average scores of items of top $27 \%$ and bottom $27 \%$ subgroups, show that the difference is significant for all items and factors. The internal consistency coefficients for all scale were found to be 0.96 for Cronbach's alpha; 0.94 for Guttman and 0.94 for Spearman-Brown. The scale format is as follows: "1-Totally Disagree", "2-Disagree," " 3-Moderately Agree", "4-Strongly Agree", 5-Totally agree ", and there is no reverse scored item. High scores obtained from the whole scale and its dimensions show that a high level of perception of school principals about their innovation management competencies.

"Innovation Management Scale for Schools" scale, developed by Bülbül (2012a), has four dimensions. These are: "Input Management", "Innovation Strategy", "Organizational Culture and Structure" and "Project Management" dimensions and they have 5, 6, 6, and 15 items respectively. Similar studies on innovation management (Adams et al., 2006; Cormican \& O'Sullivan, 2004; Smith et al., 2008) were used to determine the content of the dimensions and also for naming the dimensions.

\subsection{Data Collection and Analysis}

Research data were obtained directly by the researcher, with the application of the data collection tool to the participants of above-mentioned seminar organized by Malatya Provincial Directorate of National Education "Acquiring Formation Course Management II".

In order to reveal the school principals' perceptions about their innovation management capability, their responses to the items in the data collection tool has been analyzed. Before the analysis of the data obtained, primarily descriptive statistics are applied (Çokluk, Şekercioğlu \& Büyüköztürk, 2010) to reveal whether there had been errors in data entry or if skewness and kurtosis values of items vary between "Ғ1.50. The analysis was also checked whether outliers exist in the data set. The analysis results show that skewness and kurtosis values of the dataset ranged between $-1.26 /+1.44$ and no outliers were found.

In order to determine school principal's perceptions about their competency level of innovation management, descriptive statistical calculations on the dataset were conducted. The lowest and the highest scores, standard deviation scores and arithmetic means were calculated.

In addition, to determine School principals' perceptions of their competence level of innovation management and its relationship with personal variables, t-test and one-way variance analysis (ANOVA) were performed through the data obtained. Before the both analyzes, the data was checked for if it meets the necessary assumptions for the implementation of the test. If ANOVA test results with significant differences, the multiple comparison test was used to determine from which group or groups the difference is originated. In case of equal distribution of the group variances, Scheffe test was used for the multiple comparison of average scores (Büyüköztürk, 2010). 


\section{Results}

In this part of study, research questions considered respectively and the results were analyzed with tables.

\subsection{School Principals'Perceptions of Innovation Management and Its Dimensions}

Results of the analysis carried out to determine school principals' perceptions about innovation management and its dimensions are given in Table 1.

Table 1. Perceptions of School Principals about Innovation Management and Its Dimensions

\begin{tabular}{llcccc}
\hline Dimension & $\begin{array}{l}\text { Number } \\
\text { ofItems }\end{array}$ & $\begin{array}{l}\text { Lowest } \\
\text { Score }\end{array}$ & $\begin{array}{l}\text { Highest } \\
\text { Score }\end{array}$ & $\bar{X}$ & $\begin{array}{l}\text { Std. } \\
\text { Deviation }\end{array}$ \\
\hline Input Management & 5 & 1.80 & 5.00 & 3.70 & .66 \\
Innovation Strategy & 6 & 2.83 & 5.00 & 4.01 & .50 \\
Organizational Culture and Structure & 6 & 3.00 & 5.00 & 4.47 & .44 \\
Project Management & 15 & 3.33 & 5.00 & 4.29 & .43 \\
\hline Innovation Management Total & 32 & 3.27 & 5.00 & 4.18 & .40 \\
\hline
\end{tabular}

"Organizational Culture and Structure" dimension was found to have the highest average $(=4: 47)$ as given in Table 1. It is followed by "Project Management" (= 4.29); "Innovation Strategy" (= 4.01) and "Input Management" (= 3 to 70) dimensions. The overall average of the scale is $=4.18$. According to these results, school principals' perception of innovation management corresponds to "Totally agree" level for "Organizational Culture and Structure" and "Project Management dimensions and strongly agree for "Input Management" and "Innovation Strategy" dimensions. From the analysis of the results as a whole, it is the understood that school principals consider themselves capable at "strong" level.

\subsection{Analysis of School Principals' Perceptions of Innovation Management and its Dimensions according to Gender Variable}

The findings of the analyzes performed to determine whether the school's principals' perception of innovation management and its dimensions, varies according to gender are shown in Table 2.

Table 2. Comparison of Perceptions of School Principals about Innovation Management and Its Dimensions according to Gender Variable

\begin{tabular}{|c|c|c|c|c|c|c|c|}
\hline Dimension & Gender & $\mathrm{N}$ & $X$ & $\begin{array}{l}\text { Std. } \\
\text { Deviation }\end{array}$ & sd & $\mathrm{t}$ & $\mathrm{p}$ \\
\hline \multirow{2}{*}{ Input management } & Female & 38 & 3.70 & .66 & \multirow{2}{*}{231} & \multirow{2}{*}{.031} & \multirow{2}{*}{.97} \\
\hline & Male & 195 & 3.70 & .66 & & & \\
\hline \multirow{2}{*}{ Innovation Strategy } & Female & 38 & 3.95 & .48 & \multirow{2}{*}{231} & \multirow{2}{*}{.78} & \multirow{2}{*}{.43} \\
\hline & Male & 195 & 4.02 & .51 & & & \\
\hline \multirow{2}{*}{$\begin{array}{l}\text { Organizational } \\
\text { Culture and } \\
\text { Structure }\end{array}$} & Female & 38 & 4.42 & .42 & \multirow[b]{2}{*}{231} & \multirow[b]{2}{*}{.75} & \multirow[b]{2}{*}{.45} \\
\hline & Male & 195 & 4.48 & .44 & & & \\
\hline \multirow{2}{*}{$\begin{array}{l}\text { Project } \\
\text { Management }\end{array}$} & Female & 38 & 4.26 & .44 & \multirow{2}{*}{231} & \multirow{2}{*}{.47} & \multirow{2}{*}{.63} \\
\hline & Male & 195 & 4.29 & .43 & & & \\
\hline \multirow{2}{*}{$\begin{array}{l}\text { Innovation } \\
\text { Management Total }\end{array}$} & Female & 38 & 4.14 & .43 & \multirow{2}{*}{231} & \multirow{2}{*}{.56} & \multirow{2}{*}{.57} \\
\hline & Male & 195 & 4.18 & .40 & & & \\
\hline
\end{tabular}

T-test results shown in Table 2 reveals that no significant differences exist for the school principals' perception of innovation management, $[\mathrm{t}(231)=.56, \mathrm{p}>.05]$ according to gender.

\subsection{Analysis of School Principals'Perceptions of Innovation Management and Its Dimensions}

The findings of the analyzes performed to determine whether the school's principals' perception of innovation management and its dimensions, varies according to major field of graduation are shown in Table 3. 
Table 3. Comparison of School Principals about Innovation Management and Its Dimensions According to Major Field of Graduation Variable

\begin{tabular}{|c|c|c|c|c|c|c|c|}
\hline Dimension & Major & $\mathrm{N}$ & $X$ & $\begin{array}{l}\text { Std. } \\
\text { Deviation }\end{array}$ & $\bar{F}$ & $\mathrm{p}$ & Difference \\
\hline \multirow[t]{5}{*}{ Input Management } & 1. Natural Sciences & 36 & 3.70 & .66 & \multirow[t]{5}{*}{.012} & \multirow[t]{5}{*}{.998} & \multirow[t]{5}{*}{-} \\
\hline & 2. Social Sciences & 84 & 3.70 & .62 & & & \\
\hline & 3.Primary School Teacher & 83 & 3.70 & .72 & & & \\
\hline & 4.Fine Arts Teacher & 30 & 3.72 & .61 & & & \\
\hline & Total & 233 & 3.70 & .66 & & & \\
\hline \multirow[t]{5}{*}{ Innovation Strategy } & 1. Natural Sciences & 36 & 4.05 & .41 & \multirow[t]{5}{*}{.385} & \multirow[t]{5}{*}{.764} & \multirow[t]{5}{*}{-} \\
\hline & 2. Social Sciences & 84 & 4.00 & .50 & & & \\
\hline & 3.Primary School Teacher & 83 & 3.98 & .52 & & & \\
\hline & 4.Fine Arts Teacher & 30 & 4.08 & .57 & & & \\
\hline & Total & 233 & 4.01 & .50 & & & \\
\hline \multirow{5}{*}{$\begin{array}{l}\text { Organizational } \\
\text { Culture and Structure }\end{array}$} & 1. Natural Sciences & 36 & 4.47 & .33 & \multirow[t]{5}{*}{.303} & \multirow[t]{5}{*}{.823} & \multirow[t]{5}{*}{-} \\
\hline & 2. Social Sciences & 84 & 4.45 & .43 & & & \\
\hline & 3.Primary School Teacher & 83 & 4.50 & .47 & & & \\
\hline & 4.Fine Arts Teacher & 30 & 4.44 & .48 & & & \\
\hline & Total & 233 & 4.47 & .44 & & & \\
\hline \multirow[t]{5}{*}{ Project Management } & 1. Natural Sciences & 36 & 4.29 & .41 & \multirow[t]{5}{*}{.313} & \multirow[t]{5}{*}{.816} & \multirow[t]{5}{*}{-} \\
\hline & 2. Social Sciences & 84 & 4.26 & .41 & & & \\
\hline & 3.Primary School Teacher & 83 & 4.32 & .43 & & & \\
\hline & 4.Fine Arts Teacher & 30 & 4.27 & .51 & & & \\
\hline & Total & 233 & 4.29 & .43 & & & \\
\hline \multirow{5}{*}{$\begin{array}{l}\text { Innovation } \\
\text { Management Total }\end{array}$} & 1. Natural Sciences & 36 & 4.19 & .34 & \multirow[t]{5}{*}{.130} & \multirow[t]{5}{*}{.942} & \multirow[t]{5}{*}{-} \\
\hline & 2. Social Sciences & 84 & 4.16 & .39 & & & \\
\hline & 3.Primary School Teacher & 83 & 4.19 & .43 & & & \\
\hline & 4.Fine Arts Teacher & 30 & 4.18 & .45 & & & \\
\hline & Total & 233 & 4.18 & .40 & & & \\
\hline
\end{tabular}

One-way variance analysis (ANOVA) results in Table 3 show that, school principals' perception of innovation management, $[\mathrm{F}(3,229)=.130, \mathrm{p}<0.05]$ does not vary according to their major.

3.4 Analysis of School Principals' Perceptions about Innovation Management and Its Dimensions according to Education Level Variable

Kruskal-Wallis H-test results, performed to determine whether the school's directors' perception of innovation management and its dimensions varies according to their level of education, were shown on Table 4.

Table 4. Comparison of School Principals' Perceptions about Innovation Management and Its Dimensions according to their Education Level

\begin{tabular}{|c|c|c|c|c|c|c|c|c|c|}
\hline Dimension & Education Level & $\mathrm{N}$ & $\bar{X}$ & $\begin{array}{l}\text { Average } \\
\text { Rank }\end{array}$ & Std. Dev. & $x^{2}$ & sd & $\mathrm{p}$ & $\begin{array}{l}\text { Significant } \\
\text { Difference }\end{array}$ \\
\hline \multirow[t]{4}{*}{ Input Management } & 1.Asso. degree & 13 & 3.50 & 95.73 & .43 & \multirow[t]{4}{*}{2.216} & \multirow[t]{4}{*}{2} & \multirow[t]{4}{*}{.330} & \multirow[t]{4}{*}{-} \\
\hline & 2.Under- Graduate & 161 & 3.68 & 115.76 & .67 & & & & \\
\hline & 3.Post-Graduate & 59 & 3.80 & 125.07 & .65 & & & & \\
\hline & Total & 233 & 3.70 & & .66 & & & & \\
\hline \multirow[t]{4}{*}{ Innovation Strategy } & 1. Asso.degree & 13 & 3.87 & 104.69 & .45 & \multirow[t]{4}{*}{.469} & \multirow[t]{4}{*}{2} & \multirow[t]{4}{*}{.791} & \multirow[t]{4}{*}{-} \\
\hline & 2.Under- Graduate & 161 & 4.01 & 117.60 & .48 & & & & \\
\hline & 3.Post-Graduate & 59 & 4.04 & 118.07 & .57 & & & & \\
\hline & Total & 233 & 4.01 & & .50 & & & & \\
\hline \multirow{4}{*}{$\begin{array}{l}\text { Organizational } \\
\text { Culture and } \\
\text { Structure }\end{array}$} & 1. Asso.degree & 13 & 4.29 & 97.31 & .48 & \multirow[t]{4}{*}{1.541} & \multirow[t]{4}{*}{2} & \multirow[t]{4}{*}{.463} & \multirow[t]{4}{*}{-} \\
\hline & 2.Under- Graduate & 161 & 4.47 & 116.63 & .44 & & & & \\
\hline & 3.Post-Graduate & 59 & 4.5 & 122.35 & .40 & & & & \\
\hline & Total & 233 & 4.47 & & .44 & & & & \\
\hline \multirow{4}{*}{$\begin{array}{l}\text { Project } \\
\text { Management }\end{array}$} & 1. Asso.degree & 13 & 4.20 & 104.65 & .26 & \multirow[t]{4}{*}{1.234} & \multirow[t]{4}{*}{2} & \multirow[t]{4}{*}{.540} & \multirow[t]{4}{*}{-} \\
\hline & 2.Under- Graduate & 161 & 4.28 & 115.32 & .43 & & & & \\
\hline & 3.Post-Graduate & 59 & 4.34 & 124.31 & .44 & & & & \\
\hline & Total & 233 & 4.29 & & .43 & & & & \\
\hline \multirow{4}{*}{$\begin{array}{l}\text { Innovation } \\
\text { Management Total }\end{array}$} & 1. Asso.degree & 13 & 4.05 & 100.12 & .31 & \multirow[t]{4}{*}{1.560} & \multirow[t]{4}{*}{2} & \multirow[t]{4}{*}{.458} & \\
\hline & 2.Under- Graduate & 161 & 4.17 & 115.70 & .41 & & & & - \\
\hline & 3.Post-Graduate & 59 & 4.23 & 124.25 & .41 & & & & \\
\hline & Total & 233 & 4.18 & & .40 & & & & \\
\hline
\end{tabular}

Kruskal-Wallis H-test results in Table 4 show school principals' perception about innovation management $[(2)=1.560$, p> 0.05 ] and its dimensions have no significant differences according to their education level . 
3.5 Analysis of School Principals' Perceptions of Innovation Management and its Dimensions according to Faculty They Graduated

T-test results of School Principals' Perceptions of innovation management and its dimensions according to the faculty they graduated are given in Table 5.

T-test results reveals that no significant differences exist for the school principals' perception of innovation management, $[\mathrm{t}(231)=.857, \mathrm{p}>.05],[\mathrm{t}(231)=.56, \mathrm{p}>.05]$ according to faculty they graduated.

Table 5. Comparison of School Principals' Perceptions of Innovation Management and its Dimensions According to Faculty They Graduated

\begin{tabular}{|c|c|c|c|c|c|c|c|}
\hline Dimension & Faculty & $\mathrm{N}$ & $\bar{X}$ & $\begin{array}{l}\text { Std. } \\
\text { Deviation }\end{array}$ & sd & $\mathrm{t}$ & $\mathrm{p}$ \\
\hline \multirow[t]{2}{*}{ Input Management } & $\begin{array}{ll}\text { Faculty } & \text { of } \\
\text { Education } & \end{array}$ & 162 & 3.7196 & .69152 & \multirow[t]{2}{*}{231} & \multirow[t]{2}{*}{.489} & \multirow[t]{2}{*}{.626} \\
\hline & Other Faculties & 71 & 3.6735 & .59143 & & & \\
\hline \multirow[t]{2}{*}{ Innovation Strategy } & $\begin{array}{ll}\text { Faculty } & \text { of } \\
\text { Education } & \end{array}$ & 162 & 4.0269 & .53037 & \multirow[t]{2}{*}{231} & \multirow[t]{2}{*}{.529} & \multirow[t]{2}{*}{.597} \\
\hline & Other Faculties & 71 & 3.9887 & .44930 & & & \\
\hline \multirow{2}{*}{$\begin{array}{l}\text { Organizational } \\
\text { Culture and Structure }\end{array}$} & $\begin{array}{ll}\text { Faculty } & \text { of } \\
\text { Education } & \end{array}$ & 162 & 4.4854 & .45620 & \multirow[t]{2}{*}{231} & \multirow[t]{2}{*}{.551} & \multirow[t]{2}{*}{.582} \\
\hline & Other Faculties & 71 & 4.4507 & .40766 & & & \\
\hline \multirow[t]{2}{*}{ Project Management } & $\begin{array}{ll}\text { Faculty } & \text { of } \\
\text { Education } & \end{array}$ & 162 & 4.3103 & .42320 & \multirow[t]{2}{*}{231} & \multirow[t]{2}{*}{.998} & \multirow[t]{2}{*}{.320} \\
\hline & Other Faculties & 71 & 4.2488 & .45467 & & & \\
\hline \multirow{2}{*}{$\begin{array}{l}\text { Innovation } \\
\text { Management Total }\end{array}$} & $\begin{array}{l}\text { Faculty of } \\
\text { Education }\end{array}$ & 162 & 4.1977 & .41628 & \multirow{2}{*}{231} & \multirow{2}{*}{.857} & \multirow[t]{2}{*}{.392} \\
\hline & Other Faculties & 71 & 4.1480 & .38585 & & & \\
\hline
\end{tabular}

3.6 Analysis of School Principals' Perceptions of Innovation Management and its Dimensions according to the Stage of Schools They Work

One-way variance analysis (ANOVA) was performed in order to determine whether the School Principals' Perceptions about Innovation Management vary according to the stage of schools they work.

According to variance analysis results in Table 6, innovation management perceptions of school principals shows significant differences in innovation strategy dimension $[\mathrm{F}(3,229)=2,787, \mathrm{p}<.05]$. In order to determine the origin of difference Scheffe test as one of the multi-group comparison tests, was applied.

Accordingly, a significant difference between perceptions of the secondary stage principals and pre-school level was found. Principals who work at secondary school level have higher levels of innovation management perception compared to pre-school principals. 
Table 6. Comparison of School Principals' Perceptions of Innovation Management and its Dimensions According to the Stage of Schools They Work

\begin{tabular}{|c|c|c|c|c|c|c|c|}
\hline Dimension & $\begin{array}{l}\text { Stage of Schools They } \\
\text { Work }\end{array}$ & $\mathrm{N}$ & $X$ & Std. Dev. & $\mathrm{F}$ & $\mathrm{p}$ & Difference \\
\hline \multirow[t]{5}{*}{ Input Management } & 1.Pre-School & 31 & 3.53 & .66 & \multirow[t]{5}{*}{1.658} & \multirow[t]{5}{*}{.177} & \multirow[t]{5}{*}{-} \\
\hline & 2.Primary School & 83 & 3.67 & .71 & & & \\
\hline & 3.Middle School & 52 & 3.85 & .60 & & & \\
\hline & 4.High School & 67 & 3.70 & .62 & & & \\
\hline & Total & 233 & 3.70 & .66 & & & \\
\hline \multirow{5}{*}{$\begin{array}{l}\text { Innovation } \\
\text { Strategy }\end{array}$} & 1.Pre-School & 31 & 3.86 & .57 & \multirow[t]{5}{*}{2.787} & \multirow[t]{5}{*}{$.032 *$} & \multirow[t]{5}{*}{$3-1$} \\
\hline & 2.Primary School & 83 & 3.94 & .52 & & & \\
\hline & 3.Middle School & 52 & 4.13 & .49 & & & \\
\hline & 4.High School & 67 & 4.07 & .44 & & & \\
\hline & Total & 233 & 4.01 & .50 & & & \\
\hline \multirow{5}{*}{$\begin{array}{l}\text { Organizational } \\
\text { Culture and } \\
\text { Structure }\end{array}$} & 1.Pre-School & 31 & 4.31 & .41 & \multirow[t]{5}{*}{1.650} & \multirow[t]{5}{*}{.179} & \multirow[t]{5}{*}{-} \\
\hline & 2.Primary School & 83 & 4.50 & .46 & & & \\
\hline & 3.Middle School & 52 & 4.49 & .41 & & & \\
\hline & 4.High School & 67 & 4.50 & .43 & & & \\
\hline & Total & 233 & 4.47 & .44 & & & \\
\hline \multirow{5}{*}{$\begin{array}{l}\text { Project } \\
\text { Management }\end{array}$} & 1.Pre-School & 31 & 4.21 & .45 & \multirow[t]{5}{*}{.438} & \multirow[t]{5}{*}{.726} & \multirow[t]{5}{*}{-} \\
\hline & 2.Primary School & 83 & 4.29 & .44 & & & \\
\hline & 3.Middle School & 52 & 4.31 & .40 & & & \\
\hline & 4.High School & 67 & 4.30 & .43 & & & \\
\hline & Total & 233 & 4.29 & .43 & & & \\
\hline \multirow{5}{*}{$\begin{array}{l}\text { Innovation } \\
\text { Management Total }\end{array}$} & 1.Pre-School & 31 & 4.05 & .43 & \multirow[t]{5}{*}{1.410} & \multirow[t]{5}{*}{.241} & \multirow[t]{5}{*}{-} \\
\hline & 2.Primary School & 83 & 4.17 & .43 & & & \\
\hline & 3.Middle School & 52 & 4.24 & .38 & & & \\
\hline & 4.High School & 67 & 4.20 & .37 & & & \\
\hline & Total & 233 & 4.18 & .40 & & & \\
\hline
\end{tabular}

3.7 Analysis of School Principals' Perceptions of Innovation Management and Its Dimensions according to Their Professional Year of Experience

One-way variance analysis (ANOVA) was performed to determine whether, school principals' perceptions of innovation management and its dimensions, varies according to year of seniority.

As a result of analysis of school principals' perceptions about innovation management and its dimensions no significant difference $[\mathrm{F}(3,229)=1.811, \mathrm{p}>.05]$ was found according to their seniority levels.

Table 7. Analysis of School Principals' Perceptions of Innovation Management and Its Dimensions According to Their Professional Year of Experience

\begin{tabular}{|c|c|c|c|c|c|c|c|}
\hline Dimension & Year of seniority & $\mathrm{N}$ & $\overline{\bar{X}}$ & Std. Dev. & $\mathrm{F}$ & $\mathrm{p}$ & Difference \\
\hline \multirow[t]{5}{*}{ Input Management } & 1. $0-1$ & 64 & 3.69 & .65 & \multirow[t]{5}{*}{.236} & \multirow[t]{5}{*}{.871} & \\
\hline & 2. $2-6$ & 71 & 3.66 & .64 & & & \\
\hline & 3. $7-11$ & 41 & 3.77 & .72 & & & \\
\hline & 4. 12 and more & 57 & 3.71 & .66 & & & \\
\hline & Total & 233 & 3.70 & .66 & & & \\
\hline \multirow[t]{5}{*}{ Innovation Strategy } & 1. $0-1$ & 64 & 4.00 & .48 & \multirow[t]{5}{*}{2.312} & \multirow[t]{5}{*}{.077} & \\
\hline & 2. $2-6$ & 71 & 3.92 & .51 & & & \\
\hline & $3.7-11$ & 41 & 3.97 & .53 & & & \\
\hline & 4. 12 and more & 57 & 4.15 & .48 & & & \\
\hline & Total & 233 & 4.01 & .50 & & & \\
\hline \multirow{5}{*}{$\begin{array}{l}\text { Organizational } \\
\text { Culture and Structure }\end{array}$} & 1. $0-1$ & 64 & 4.45 & .44 & \multirow[t]{5}{*}{.673} & \multirow[t]{5}{*}{.570} & \\
\hline & 2. $2-6$ & 71 & 4.45 & .44 & & & \\
\hline & 3. $7-11$ & 41 & 4.44 & .46 & & & \\
\hline & 4. 12 and more & 57 & 4.54 & .41 & & & \\
\hline & Total & 233 & 4.47 & .44 & & & \\
\hline \multirow[t]{5}{*}{ Project Management } & 1. $0-1$ & 64 & 4.29 & .44 & \multirow[t]{5}{*}{2.679} & \multirow[t]{5}{*}{.058} & \\
\hline & 2. $2-6$ & 71 & 4.22 & .42 & & & \\
\hline & $3.7-11$ & 41 & 4.22 & .48 & & & \\
\hline & 4. 12 and more & 57 & 4.42 & .36 & & & \\
\hline & Total & 233 & 4.29 & .43 & & & \\
\hline \multirow{5}{*}{$\begin{array}{l}\text { Innovation } \\
\text { Management Total }\end{array}$} & 1. $0-1$ & 64 & 4.17 & .38 & \multirow[t]{5}{*}{1.811} & \multirow[t]{5}{*}{.146} & \\
\hline & 2. $2-6$ & 71 & 4.12 & .40 & & & \\
\hline & 3. $7-11$ & 41 & 4.14 & .48 & & & \\
\hline & 4. 12 and more & 57 & 4.28 & .36 & & & \\
\hline & Total & 233 & 4.18 & .40 & & & \\
\hline
\end{tabular}


3.8 Analysis of School Principals' Perceptions of Innovation Management and Its Dimensions according to Number of Students in the School Variable

One-way variance analysis (ANOVA) was performed to determine whether, school principals' perceptions about innovation management and its dimensions, varies according to the number of students in the school they currently work in.

According to variance analysis results in Table 8, innovation management perceptions of school principals shows significant difference $[\mathrm{F}(3,229)=3.505, \mathrm{p}<.05]$. In order to determine the origin of difference Scheffe test was carried out and as a result, a significant difference between perceptions of the least crowded (0-199) schools' and most crowded (600 or more) schools' principals was found. In addition, principals who work at schools with 600 or more students have higher mean score in the "Input Management" dimension compared to principals who works at schools with 0-199 students.

Table 8. Comparison of School Principals' Perceptions of Innovation Management and its Dimensions According to Number of Students in the School Variable

\begin{tabular}{|c|c|c|c|c|c|c|c|}
\hline Dimension & Number of Students & $\mathrm{N}$ & $X$ & $\begin{array}{l}\text { Std. } \\
\text { Deviation }\end{array}$ & $\mathrm{F}$ & $\mathrm{p}$ & Difference \\
\hline \multirow[t]{4}{*}{ Input Management } & 1. $01-199$ & 99 & 3.58 & .63 & \multirow[t]{4}{*}{3.505} & \multirow[t]{4}{*}{$.023 *$} & \multirow[t]{4}{*}{$3-1$} \\
\hline & 2. $200-599$ & 85 & 3.74 & .70 & & & \\
\hline & 3. 600 and more & 49 & 3.88 & .60 & & & \\
\hline & Total & 233 & 3.70 & .66 & & & \\
\hline \multirow{4}{*}{$\begin{array}{l}\text { Innovation } \\
\text { Strategy }\end{array}$} & 1. $0-199$ & 99 & 3.95 & .54 & \multirow[t]{4}{*}{1.383} & \multirow[t]{4}{*}{.253} & \\
\hline & 2. $200-599$ & 85 & 4.06 & .49 & & & \\
\hline & 3. 600 and more & 49 & 4.06 & .43 & & & \\
\hline & Total & 233 & 4.01 & .50 & & & \\
\hline \multirow{4}{*}{$\begin{array}{l}\text { Organizational } \\
\text { Culture and } \\
\text { Structure }\end{array}$} & $\begin{array}{ll}1 . & 0-199 \\
\end{array}$ & 99 & 4.40 & .45 & \multirow[t]{4}{*}{2.324} & \multirow[t]{4}{*}{.100} & \\
\hline & $2.200-599$ & 85 & 4.54 & .43 & & & \\
\hline & 3.600 and more & 49 & 4.50 & .42 & & & \\
\hline & Total & 233 & 4.47 & .44 & & & \\
\hline \multirow{4}{*}{$\begin{array}{l}\text { Project } \\
\text { Management }\end{array}$} & 1. $0-199$ & 99 & 4.28 & .44 & \multirow[t]{4}{*}{.155} & \multirow[t]{4}{*}{.857} & \\
\hline & $2.200-599$ & 85 & 4.31 & .45 & & & \\
\hline & 3. 600 and more & 49 & 4.27 & .36 & & & \\
\hline & Total & 233 & 4.29 & .43 & & & \\
\hline \multirow{4}{*}{$\begin{array}{l}\text { Innovation } \\
\text { Management Total }\end{array}$} & 1. $0-199$ & 99 & 4.13 & .42 & \multirow[t]{4}{*}{1.234} & \multirow[t]{4}{*}{.293} & \\
\hline & $2.200-599$ & 85 & 4.21 & .41 & & & \\
\hline & 3. 600 and more & 49 & 4.21 & .34 & & & \\
\hline & Total & 233 & 4.18 & .40 & & & \\
\hline
\end{tabular}

3.9 Analysis of School Principals' Perceptions of Innovation Management and its Dimensions according to Number of Teachers in the School Variable

One-way variance analysis (ANOVA) was performed to determine whether, school principals' perceptions about innovation management and its dimensions, varies according to the number of teachers in the school they currently work in.

From Table 9 it is observed that; school principals' perceptions about whole Scale of Innovation Management [F ( 2 , $230)=3.334, \mathrm{p}<.05]$, Input Management $[\mathrm{F}(2,230)=6.208, \mathrm{p}<.05]$ and Innovation Strategy dimension $[\mathrm{F}(2$, $230)=4,782, \mathrm{p}<.05]$ differ significantly according to the number of teachers in schools that serve. Scheffe test was performed to determine the source of the difference. Accordingly, the difference was emerged between the schools which have 1-20 number of teachers and schools with 41 and above number of teachers and this difference was found to be in favor of schools that have with 41 and more teachers.

There was no significant differences for the other dimensions; Project Management $[\mathrm{F}(2,230)=.626, \mathrm{p}>.05]$ and Organizational Culture and Structure $(2,230)=2.109, \mathrm{p}>.05]$. 
Table 9. Comparison of School Principals' Perceptions of Innovation Management and its Dimensions According to Number of Teachers in the School Variable

According to Number of Teachers in the School Variable

\begin{tabular}{|c|c|c|c|c|c|c|c|}
\hline Dimension & $\begin{array}{l}\text { Number } \\
\text { Teachers }\end{array}$ & $\mathrm{N}$ & $\bar{X}$ & $\begin{array}{l}\text { Std. } \\
\text { Deviation }\end{array}$ & $\mathrm{F}$ & $\mathrm{p}$ & Difference \\
\hline \multirow{4}{*}{$\begin{array}{l}\text { Input } \\
\text { Management }\end{array}$} & 1. $1-20$ & 126 & 3.56 & .71 & \multirow[t]{4}{*}{6.208} & \multirow[t]{4}{*}{$.002 *$} & \multirow[t]{4}{*}{ 3-1 } \\
\hline & 2. $21-40$ & 65 & 3.83 & .56 & & & \\
\hline & 3.41 and more & 42 & 3.90 & .55 & & & \\
\hline & Total & 233 & 3.70 & .66 & & & \\
\hline Innovation & 1. $1-20$ & 126 & 3.92 & .50 & \multirow[t]{4}{*}{4.782} & \multirow[t]{4}{*}{$.008 *$} & \multirow[t]{4}{*}{$3-1$} \\
\hline \multirow[t]{3}{*}{ Strategy } & $2.21-40$ & 65 & 4.10 & .52 & & & \\
\hline & 3.41 and more & 42 & 4.15 & .44 & & & \\
\hline & Total & 233 & 4.01 & .50 & & & \\
\hline \multirow{4}{*}{$\begin{array}{l}\text { Organizational } \\
\text { Culture and } \\
\text { Structure }\end{array}$} & 1. $1-20$ & 126 & 4.42 & .44 & \multirow[t]{4}{*}{2.109} & \multirow[t]{4}{*}{.124} & \multirow[t]{4}{*}{ - } \\
\hline & $2.21-40$ & 65 & 4.51 & .44 & & & \\
\hline & 3.41 and more & 42 & 4.56 & .42 & & & \\
\hline & Total & 233 & 4.47 & .44 & & & \\
\hline \multirow{4}{*}{$\begin{array}{l}\text { Project } \\
\text { Management }\end{array}$} & 1. $1-20$ & 126 & 4.26 & .42 & \multirow[t]{4}{*}{.626} & \multirow[t]{4}{*}{.536} & \multirow[t]{4}{*}{ - } \\
\hline & $2.21-40$ & 65 & 4.31 & .47 & & & \\
\hline & 3. 41 and more & 42 & 4.33 & .39 & & & \\
\hline & Total & 233 & 4.29 & .43 & & & \\
\hline \multirow{4}{*}{$\begin{array}{l}\text { Innovation } \\
\text { Management } \\
\text { Total }\end{array}$} & 1. $1-20$ & 126 & 4.12 & .41 & \multirow[t]{4}{*}{3.334} & \multirow[t]{4}{*}{$.027 *$} & \multirow[t]{4}{*}{ 3-1 } \\
\hline & 2. $21-40$ & 65 & 4.24 & .40 & & & \\
\hline & 3. 41 and more & 42 & 4.27 & .36 & & & \\
\hline & Total & 233 & 4.18 & .40 & & & \\
\hline
\end{tabular}

\section{Discussion}

This study is aimed to determine the perceptions of school principals about innovation management and to investigate whether there is a significant difference in this perception according to various parameters. According to results, school principals" perceptions of innovation management as a whole correspond to "strongly agree"; so that school principals consider themselves capable at "strong" level.

According to dimensions, school principals' perceptions of innovation management correspond to "totally agree" level for "Organizational Culture and Structure" and "Project Management" dimensions and "strongly agree" for "Input Management" and "Innovation Strategy" dimensions. However, when the results are evaluated according to points, the lowest point is for "Input Management" and it is followed respectively as "Innovation Strategy" and "Project Management". The highest point is for "Organizational Culture and Structure". It is seen that there have been similar results in other studies about innovation management (Göl \& Bülbül, 2012; Karataş, Gök \& Özçetin; 2015).

Results show that principals are more successful in the dimensions of "Project Management" and "Organizational Culture and Structure". They also find themselves adequate about being open towards innovation, internalizing it and making suitable it for school implementations. Besides these, integrating all the members to the innovation process, using the school resources for modern practices, supporting and following the implementation process of new projects are the other things that the principals feel themselves successful. Such a result has also been obtained in the study of Göl \&Bülbül (2012). In their researches, they studied on the perceptions of teachers about their school principals.

Principals' perceptions of innovation management and its dimensions are also taken into account according to some variables. Results reveal that no significant differences exist for the school principals' perception of innovation management according to gender, major, education level, faculty, and their professional year of experience.

However, it is determined that male principals have higher points about their perception of innovation management and its dimensions when compared to their female colleagues. Males find themselves more successful than females about starting, continuing and ending the innovation process.

For the gender variable, all the principals' innovation management perceptions are very similar and center in "strongly agree" level.

Although results show that school principals' perception about innovation management and its dimensions have no significant difference according to their education level; it is also seen that there is a direct correlation between education level and perception of principals' innovation managing skills. When the education level increases, the perceptions also increase. The principals with post-graduate degree perceive themselves more successful when compared to principals with associate degree and undergraduate degree. 
It seems that principals graduate of education faculty are more successful about managing innovation process in their school. This result can be interpreted as education faculties' human training policy (Kaya, 1984), which reveals graduates with high qualities.

Although result of analysis shows that there is no significant difference according to seniority levels of principals; principals with 12 or more years of seniority perceive themselves more adequate by comparison to other groups of seniority. So, there is a direct correlation between years of seniority and perception of principals' innovation managing skills. We may explain this result by principals' internalizing their profession, giving more importance to develop their school and their bureaucratic socialization. However, some research results don't match with this finding (Boydak-Ozan \& Karabatak, 2013).

It is found that, there is a significant difference between perceptions of the secondary stage principals and pre-school level. Principals who work at secondary school level have higher levels of innovation management perception compared to pre-school principals. Moreover to this result; middle and high school principals' perceptions of innovation management correspond to "totally agree" while Pre-School and Primary School principals' perceptions of innovation management correspond to "strongly agree" level. Accordingly, when the education level rises up the perceptions do, too.

Innovation management perceptions of principals show significant difference according to the number of teachers and students in the school. Principals' perceptions about whole Scale of Innovation Management, Input Management and Innovation Strategy dimension differ significantly according to the number of teachers in schools they serve. Accordingly, the difference was emerged between the schools which have 1-20 number of teachers and schools with 41 and above number of teachers. The positive effect of the number of teachers may be explained as principals' giving more importance to include teacher potential in the innovation process of the school and creating much more projects by the help of this teacher potential.

Analysis results revealed that there is a significant difference between perceptions of the least crowded (0-199) schools' and most crowded (600 or more) schools' principals. Principals who work at schools with 600 or more students have higher mean score in the "Input Management" dimension compared to principals who works at schools with 0-199 students. This finding can be explained as the reflection of students' potential to the school and youngsters' interest towards innovation.

When the results of the research are examined as a whole, it can be concluded that today, our schools have principals who are aware of the importance of innovation and innovation management. That can be accepted as a big acquisition for the Turkish education system because only with such awareness, innovations would be permanent and any transformation and improvement required by the 21 th century will be able to put into practice. It can be deducted from this result that the success of schools on innovation management would effect the development, transformation and innovation process of the society as well.

\section{References}

Adair, J. (2008). Yenilikçi liderlik. İstanbul: Babıâli Kültür.

Adams, R., Bessant, J., \& Phelps, R. (2006). Innovation management measurement: A review. International Journal of Management Reviews, 8(1) 21-47. http://dx.doi.org/10.1111/j.1468-2370.2006.00119.x

Ağıroğlu, B. A., \& Aslan, M. (2014). Paylaşılan liderliğin öğretmenlerin örgütsel bağlllı̆̆ üzerindeki etkisi. e-International Journal of Educational Research, 5(3), 5671.

Ak, M. (2006). İlköğretim Okulu Yöneticilerinin Değişimi Yönetme Yeterlikleri. Yayınlanmamış Yüksek Lisans Tezi, Afyon Kocatepe Üniversitesi Sosyal Bilimler Enstitüsü, Afyonkarahisar.

Argon, T., \& Özçelik, N. (2008). İlköğretim okulu yöneticilerinin değişimi yönetme yeterlikleri. Mehmet Akif Ersoy Üniversitesi Eğitim Fakültesi Dergisi, 8(16), 70-89.

Aslan, M., \& Ağıroğlu, B. A. (2015). Okul örgütlerinde paylaşılan liderlik ölçeği: geçerlik ve güvenirlik çalışması. Kuram ve Uygulamada Eğitim Yönetimi, 21(1), 1-24. http://dx.doi.org/10.14527/kuey.2015.001

Beycioğlu, K., \& Aslan, M. (2010). Okul Gelişiminde Temel Dinamik Olarak Değişim ve Yenileşme: Okul Yöneticileri ve Öğretmenlerin Rolleri. Yüzüncü Yıl Üniversitesi Eğitim Fakültesi Dergisi, 7(1), 153-173.

Borgelt, K., \& Falk, I. (2007). The leadership/management conundrum: innovation or risk management?. Leadership \& Organization Development Journal, 28(2), 122-136. http://dx.doi.org/10.1108/01437730710726822

Boydak, O. M., \& Karabatak, S. (2013). Ortaöğretim okul yöneticilerinin yenilik yönetimine yaklaşımları ve karşılaştıkları sorunlar. International Online Journal of Educational Sciences, 5(1), 258-273. 
Bülbül, T. (2012a). Okullarda yenilik yönetimi ölçeği’nin geliştirilmesi: Geçerlik ve güvenirlik çalışması. Kuram ve Uygulamada Eğitim Bilimleri, 12(1), 157-175.

Bülbül, T. (2012b). Okul yöneticilerinin yenilik yönetimine ilişkin yeterlik inançları. Trakya Üniversitesi Sosyal Bilimler Enstitüsü Dergisi, 14(1), 45-68.

Büyüköztürk, Ş. (2010). Sosyal bilimler için veri analizi el kitabı: İstatistik, araştırma deseni, SPSS uygulamaları ve yorum. Pegem Akademi. Ankara.

Çokluk, Ö., Şekercioğlu, G., \& Büyüköztürk, Ş. (2010). Sosyal bilimler için çok değgişkenli istatistik: SPSS ve LISREL uygulamaları. Pegem Akademi. Ankara

Comeaux, E. (2013). Rethinking academic reform and encouraging organizational innovation: Implications for stakeholder management in college sports. Innovative Higher Education,38(4), 281-293. http://dx.doi.org/10.1007/s10755-012-9240-1

Cormican, K., \& O'Sullivan, D. (2004). Auditing best practice for effective product innovation management. Technovation, 24(10), 819-829. http://dx.doi.org/10.1016/S0166-4972(03)00013-0

Fullan, M. (1992). Successful school improvement: The implementation perspective and beyond. McGraw-Hill Education (UK).

Fullan, M. (2002a). Principals as leaders in a culture of change. Educational leadership, 59(8), 16-21.

Fullan, M. (2002b). The role of leadership in the promotion of knowledge management in schools. Teachers and Teaching: theory and practice, 8(3), 409-419.

Fullan, M. (2007). The new meaning of educational change. 4th. Edition. Routledge.

Fullan, M. (2014). Leading in a culture of change personal action guide and workbook. John Wiley \& Sons.

Göl, E. (2012) İlköğretim Okulu Yöneticilerinin Yenilik Yönetimi Yeterliklerine İlişkin Öğretmen Algıları (Kırklareli İli Örneği). Yüksek Lisans Tezi.Trakya Üniversitesi, Edirne.

Göl, E., \& Bülbül, T. (2012). İlköğretim okulu yöneticilerinin yenilik yönetimi yeterliklerine ilişkin öğretmen algıları. Mersin Üniversitesi Ĕgitim Fakültesi Dergisi, 8(2), 97-109.

Goyal, S., \& Pitt, M. (2007). Determining the role of innovation management in facilities management, Facilities, Vol. 25(1/2), 48-60. http://dx.doi.org/10.1108/02632770710716939

Harris, A., Day, C., Hopkins, D., Hadfield, M., Hargreaves, A., \& Chapman, C. (2003), Effective Leadership for School Improvement, RoutledgeFalmer, New York, NY.

Helvac1, M. A. (2004). Resmi İlköğretim Okullarında Görev Yapan İlköğretim Okul Yöneticilerinin Değişimi Yönetme Yeterliklerinin Değerlendirilmesi. Yayınlanmamış Doktora Tezi, Ankara Üniversitesi Eğitim Bilimler Enstitüsü, Ankara.

Kabakçı, H. (2008). Eğitimde yenileşme çalışmaları ve öğretmenlerin ilçe milli eğitim müdürlüğü çalışmalarındaki yenileșme ve yeterliklere yönelik algı ve beklentileri (Kandıra Örneği). Yayınlanmamış yüksek lisans tezi. Yeditepe Üniversitesi/Sosyal Bilimler Enstitüsü, İstanbul.

Karasar, N. (2008). Bilimsel araştırma yöntemi. Ankara: Nobel Yayın Dağıtım.

Karataş, S., Gök, R., \& Özçetin, S. (2015). Okul yöneticilerinin yenilik yönetimi yeterliklerine ilişkin öğretmen algıları. Mehmet Akif Ersoy Üniversitesi Eğitim Fakültesi Dergisi, 1(33), 167-185.

Kaya, Y. K. (1984). Insan yetiştirme düzenimiz: politika, eğitim, kalkınma. Erk Basimevi, 3.

Markee, N. (1997). Managing Curricular Innovation.Cambridge University Press.

Matthews, J. H. (2003). Knowledge management and organizational learning: Strategies and practices for innovation. In Easterby-Smith, Mark, (Eds). Proceedings Organizational Learning and Knowledge-Fifth International Conference, Lancaster University Management School, United Kingdom. http://eprints.qut.edu.au/14632/

OECD (2001), Cities and Regions in the New Learning Economy, OECD, Paris.

Özdemir, S., \& Cemaloğlu, N. (2000). Eğitimde örgütsel yenileşme ve karara katılma. Milli Eğitim Dergisi, 146(2), 54-63.

Perillo, S. (2007). Tension as an enabling characteristic of innovating in schools. International Journal of Educational Management, 21(7), 621-633. http://dx.doi.org/10.1108/09513540710822210

Smith, M., Busi, M., Ball, P., \& Van Der Meer, R. (2008). Factors influencing an organisation's ability to manage 
innovation: a structured literature review and conceptual model. International Journal of innovation management, 12(04), 655-676. http://dx.doi.org/10.1142/S1363919608002138

Sönmez, Y. (2005). Eğitim Örgütlerinde Değişim Sürecinde İnsan Unsuru ve Okul Yöneticilerinin Rolleri. Yayınlanmamış Yüksek Lisans Tezi, Fırat Üniversitesi Sosyal Bilimler Enstitüsü.

Sultana, R. G. (2001). Educational Innovation in the Context of Challenge and Change: a Euro-Mediterranean Perspective. Challenge and Change in the Euro-Mediterranean Region. (Ed: Sultana, Ronald G.) New York: Peter Lang Publishing, Inc.

Taş, S. (2007). Eğitimde yenileşmenin önündeki engeller (Dört Köşe Tekerlekler). Süleyman Demirel Üniversitesi Sosyal Bilimler Dergisi, 17, 183-192.

TDK. (2015). Güncel Türkçe Sözlük. http://tdk.gov.tr/index.php?option=com_gts\&view=gts.

Top, M. Z. (2011). İlköğretim okul yöneticilerinin yenilik yönetimine ilişkin tutumlarının incelenmesi. Marmara Üniversitesi, Eğitim Bilimleri Enstitüsü, Yayınlanmamış Yüksek Lisans Tezi

Uzkurt, C. (2008). Yenilik yönetimi ve yenilikçi örgüt kültürü̈. İstanbul: Beta Basım Yayın

Van den Berg, R., Vandenberghe, R., \& Sleegers, P. (1999). Management of innovations from a cultural-individual perspective. School Effectiveness and School Improvement, 10(3), 321-351. http://dx.doi.org/10.1076/sesi.10.3.321.3500

Wiseman, A. W. (2014). Promises and Challenges for Innovation and Entrepreneurship in Education. In International Educational Innovation and Public Sector Entrepreneurship (pp. 251-274). Emerald Group Publishing Limited. http://dx.doi.org/10.1108/s1479-3679(2013)0000023019

\section{$(\mathrm{Cc}) \mathrm{BY}$}

This work is licensed under a Creative Commons Attribution 3.0 License. 